with mesons and the way in which research workers hope to produce these particles artificially with the synchrotron.

Throughout the meeting exhibitions of scientific apparatus and scientific text-books were well attended by members and visitors, and one large laboratory was used for displaying apparatus invented, improved and constructed by science masters and their pupils,

Visits were arranged to a well-known shipbuilding yard, to chemical, optical and engineering works, to the Scottish Central Film Library and to Yoker Power Station. The final visit of the meeting took place on March 31 to the Loch Sloy Hydro-Electric Station on the banks of Loch Lomond. Here the members were shown over the generating room and the control room, but owing to a heavy fall of snow the visit to the dam some distance from the Station had to be cancelled.

\section{ELECTRON MICROSCOPY IN GERMANY}

$\mathrm{T}$

HE electron microscope was invented in Germany, and its subsequent development into a standard research tool took place almost entirely in German laboratories until the outbreak of the Second World War in 1939. A considerable volume of work continued to be published until 1944. Throughout this period a very marked rivalry existed between three laboratories (those of Siemens-Halske, the AEG, and von Ardenne), which led to the duplication and even triplication of many investigations, and undoubtedly hindered the development of electron microscopy in wider fields. New techniques, rather than fruitful applications, were pursued, and the urgently necessary critical comparison with optical methods was neglected. Later work in the United States, Great Britain and France took a more balanced course, and has led to important contributions, especially in bacteriology and metal physics. Societies for furthering the new method were founded early in both Great Britain and the United States.

After the War most of the electron microscopes in Germany were removed by one or other of the victorious Allies (in roughly equal shares) and research teams were dispersed. However, with characteristic diligence, the production of improved models was quickly recommenced and the new models were put to use in many researches. A new spirit of co-operation also became apparent, and the first conference devoted solely to electron microscopy was held in 1949, as a result of which a Deutsche Gesellschaft für Elektronenmikroskopie was founded. Its formal inauguration took place at the second meeting, held at Bad. Soden in April 1950, the proceedings of which are now recorded in a special number of the journal Optik*.

The number and range of the contributions in this volume testify to the rapidity of the rebirth of the subject in Germany. Indeed, when the extent of the disorganization due to the War is taken into account, the volume and quality of the work reported are quite remarkable. Forty-two papers cover the theory and construction of the instrument, its specimen techniques and their application in physics, chemistry, technology and many branches of biology. Much of the work is in similar directions to that being

* Optik, 7, part 4-6 (1950): Report of Second Conference of the Deutsche Gesellschaft für Elektronenmikroskopie (Stuttgart).
D.M. 7. pursued elsewhere, such as the comparison of the electron with optical and phase-contrast results, the reliability of replica methods, and the study of the detailed morphology of bacteria and viruses. Some investigations of special interest deserve mention. K. Beyersdorfer has studied the structure of graphite oxide, and E. Zehender that of evaporated films of zinc and cadmium. An extended investigation is reported by G. Pfefferkorn of the surface of calcite, both of natural cleavage faces and after etching, while A. Schrader compares the optical and electron-microscopical pictures of pearlitic structures in various steels. H. König is investigating the effect of the electron beam on specimens, par. ticularly those of a biological nature. The fibrous structure of the vitreous humour of the eye has been studied by H. Ruska, and the fine structure of nerves by A. Jakob.

The report as a whole, running to some 150 pages, will provide the specialist in electron microscopy with much that is new, and at the same time show the general reader the wide scope which it now embraces.

V. E. Cossletit

\section{BUILDING RESEARCH BOARD ANNUAL REPORT FOR 1949}

$7 O$ those who have been fortunate enough to build since the War, whether house, office or factory, there is little to show that building research has continued. Plaster still cracks abominably, heating systems are too often poorly designed and inefficient, and plumbing seems as primitive and noisy as ever. However, the Director of Building Research makes it clear in his report for $1949^{*}$ that these or related problems have received attention during the year, so that the shortcomings must be blamed on the unsuitability of materials readily available to-day, on poor craftsmanship or, perhaps, on the failure of the builder and manufacturer to reap the fruits of research.

The position seems to be different where monumental building is concerned. The Royal Festival Hall, on the South Bank site, London, has just been completed, and from what one has seen and from the account recently given by two of the engineers concerned, Messrs. E. O. Measer and D. H. New, in a paper read before the Institution of Civil Engineers, the results of researches in structures and materials were used and the staff of the Building Research Station were called upon directly to make surveys and to carry out investigations on the site so as to help in providing a successful solution to the difficult acoustic problem which naturally arose from placing a great concert hall in close proximity to Hungerford Bridge, which is a busy railway bridge crossing the Thames. It may be that the civil engineering contractor is more aware of the benefits to be derived from the adoption of scientific methods than the builder or, due to the higher proportion of university graduates employed by him, is in a better position to adopt them without loss of time. This state of affairs may have influenced the Building Research Board in its choice of problems, because it is clear from the 1949 report that a considerable proportion of the Building Research Station's effort is directed

* Department of Scientific and Industrial Research. Report of the Building Research Board with the Report of the Director of Building Research for the Year 1949. Pp. iv $+60+16$ plates. (London: H.M. Stationery Office, 1950.) 3s. net. 
to civil engineering work rather than to what is popularly understood by building. Into this civil engineering category falls the work on highway bridges, on reinforced concrete structures and steel frameworks, and much of that on soil mechanics.

The investigation of the behaviour of composite steel - reinforced-concrete bridge deck slabs was continued during 1949, laboratory tests being carried out on a one-third scale slab, and full-scale tests were made, for the Ministry of Transport, to show the dynamic effect of a vehicle passing over a bridge. Some attention was also given to that interesting form of construction, the concrete shell roof, for which an entirely satisfactory method of design has yet to be developed. A test of a $60-\mathrm{ft}$. span shell barrel vault was made, and it is interesting to note that under a 50 per cent overload the deflexions were only of the same order as those observed due to temperature changes. Forty pre-stressed concrete floor-joists were tested for the Ministry of Works and investigation of the impact strength has been started ; but there is no mention of more fundamental work on this material. It is satisfactory to see that once more the Station is giving some attention to the design of steel building-frames and that, using the same technique as was developed twenty years ago when the behaviour of a number of London buildings was investigated for the Steel Structures Research Committee, strain gauges have been fitted to the new Government buildings in Whitehall Gardens so that the stresses in the steelwork can be observed during each stage of building and during subsequent occupation. Laboratory tests designed to measure the effect of cladding, brick panel walls and reinforced concrete floors in relieving the steel framework are also reported as being carried out.

The activity of the Soil Mechanics Section during the year has been limited to three main lines: the study of the bearing capacity of soils in relation to foundations for large structures; excavations in difficult ground; and the stability of earth banks. On the theoretical side a general solution based on a theory of plasticity has been obtained for calculating an approximate value of the bearing capacity of foundations of all types, including footings and piles, in terms of the shear characteristics of the soil. Tables and graphs giving these bearing capacity factors have been completed for both clays and sands. A series of model tests has been carried out in the laboratory, using footings of various sizes and shapes located at different depths beneath the surface, and the results obtained so far have shown promising agreement with the theory. A study of the stability of the bottom of an excavation carried into water-bearing ground was being made, and results, summarized in a number of graphs, have already been obtained which should be of assistance to engineers in assessing the depth of penetration of sheeting necessary to ensure stability of the bottom of an excavation. Advice on the design, construction and maintenance of banks has been given to several river catchment boards, and work on electro-osmosis in soils has been continued.

In the building, as distinct from the civil engineering, field, interesting work has been carried out on the development of a satisfactory method of providing short bored pile foundations for houses on clay soils. Data of the safe bearing-capacity of such piles are now available, and the dimensions of suitable reinforced concrete beams, to span the pile heads and carry the house walls efficiently, have been determined.

A block of four houses, completed in March 1949, was being used for a study of heating by the circulation of warm air, and two blocks of flats, under construction in the ancient village of Abbots Langley, were to be used for a full-scale investigation into methods of sound insulation. The need for these will be fully appreciated by those who live in orthodox houses built since the War, with floor joists of reduced depth and plaster-board ceilings, which make it possible for the children in bed to converse with ease with their parents in the sittingroom below.

It is clear from this report that, though some builders and architects may still not make full use of it, the Building Research Station, which now has a branch laboratory in Scotland and close contacts with the British Colonies, is doing great work, particularly on the practical side, and is making it known. Almost five thousand inquiries, an increase of 859 over 1948, were received during the year, and ten thousand requests for sources of information or copies of publications were dealt with by the Station library.

\section{FOREST PRODUCTS RESEARCH BOARD \\ ANNUAL REPORT FOR 1948}

A

$S$ an aftermath of the Second World War, work on research in many forest-products labora. tories has had to be to some extent reorientated, as, for example, the great Madison Laboratory in the United States and the Research Institute at Dehra Dun and elsewhere. In the report for 1948 of the Forest Products Research Board and of the Forest Products Research Laboratory at Princes Risborough*, it is stated that during 1948 the highest priority was given in the programme of the Laboratory to those projects which bore upon the amelioration of the national timber situation, namely, to the accumulation of test and utilization data of new timbers, the search for substitute timbers and more efficient utilization. These investigations, mostly on timbers from Colonial sources, together with the very large volume of advisory and short-term work, now absorb most of the available time.

So far as the tropical and sub-tropical forests are concerned, it is very encouraging for the officers managing these forests to find that the possibilities have increased of being able to sell an increasing number of species of the mixed forest. Sylviculturally, it will render the work of obtaining the new crops to replace the old both more fascinating and, it may be hoped, easier. As in the past, one of the other staff usually called in when new timbers are coming up for consideration is the entomologist. Perhaps his investigations nowadays are more in connexion with the pinhole borers in hardwoods than in the oldtime barkbeetle troubles with conifers.

The amount of advisory work in the Laboratory again exceeded the previous year by 10-15 per cent, and most of the time accruing from the recruitment of new staff has been taken up in dealing with it and with the tests on new Colonial timbers.

* Department of Scientific and Industrial Research. Report of the Forest Products Research Board, with the Report of the Director of forest Products Research, for the Year 1948. Pp. v $+46+12$ plates. (London: H.M. Stationery Office, 1950.) 2s. net. 